J. of Korean Inst. of Resources Recycling

Vol. 20, No. 6, 2011, 3-18

$》$ 總 設 $\ll$

韓國의 都市鑛山(사용후제家) 資源과 金屬再資源化 ${ }^{\dagger}$

中吳在賢 $\cdot$ 金俊秀* · 文碩敏 $* *$ 閔芝源 $* * *$

延世大學校 名譽敎授, *韓國地質資源研究院, **ACN, ***韓國資源己씨이클링學會

\title{
Urban Mine Resources and Metal Recycling in Korea ${ }^{\dagger}$
}

‡Jae-Hyun Oh, Joon-Soo Kim*, Suk-Min Moon** and Ji-Won Min***

Professor Emeritus of Yonsei University,

*Korea Institute of Geoscience and Mineral Resources, **ACN,

***The Korean Institute of Resources Recycling

\section{요 약}

우리나라의 도시광산 재자원화실태와 전망을 파악하기 위하여 금속소비량을 산출하였다. 년간 금속소비량으로부터 금속 축적량 을 추정할 수 있고, 도시광산자원을 전망할 수 있다. 금속소비량을 산출함에 있어 다양한 자료 즉 비철협회, 철강협회, 관세청 HS 코드, 연구용역 보고서, 학술회의자료 및 생산회사 탐문자료 등을 인용하였다. 도시광산개발의 요건(key point)을 설명하기 위하여 T.E.Graedel에 의해서 작성된 표(Principle Uses and Recycling Potential of Metals in the Periodic Table)를 인용하였다.

주제어 : 금속소비량, 금속축적량, 고철리싸이클링, 자동차리싸이클링, E-waste 리싸이클링

\begin{abstract}
In order to review the recycling status of urban mine resources in Korea, metal consumption, metal stock reserves and metal scraps and wastes such as iron scrap, end of life vehicles(ELV), E-waste were surveyed. In making up the list of the metal consumption, the statistical data from the Korea Non-Ferrous Association, the Korea Iron and Steel Association, the HS code of Korea Custom Service, the symposium and the related companies were collected. Finally, "Principle uses and recycling potential of metals in the periodic table" by T.E.Graedel was introduced. This paper suggested the key point for development of urban mine resources.
\end{abstract}

Key words : Recycling, Iron scrap, ELV, E-waste

\section{1. 머리말}

자연광산이나 도시광산이나 그 개발에 있어서 가장 중요한 요소는 매장량과 품위이다. 도시광산의 매장량 은 금속축적량으로 추정할 수 있고, 금속축적량은 금속 소비량으로부터 추정할 수 있다. 이러한 까닭에 본고에 서는 한국의 금속소비량을 탐색하고 산출하는데 정성을 다하였다. 본고에서 제시한 한국의 금속소비량 표는 완

\footnotetext{
†2011년 10월 27일 접수, 2011년 11월 21일 수정

2011년 12월 7일 수리

*E-mail: kirr@kirror.kr
}

벽한 것은 아니더라도, 40 종의 금속소비량 통계표를 처 음으로 발표한 점에서, 이 통계표가 여러분에 의해서 수 정 - 보완되어 신뢰성이 두터운 자료가 구축될 것이라는 기대감에서 그 의의를 찾고 싶다. 한편, T.E.Graedel ${ }^{1)}$ 에 의해서 작성된 각종 금속의 용도와 재자원화 타당성 (recycling potential)을 나타낸 표는 도시광산 개발의 타 당성을 검토하는데 많은 것을 시사하고 있다.

본고에서는 이상의 기술(記述) 이외에 한국의 도시광 산 재자원화산업, 즉 고철, $\mathrm{ELV}$ (End of life vehicle), E-waste(WEEE), 사업장폐기물(석유탈황폐촉매, EAF더 스트)에 관해서 약술하였다. 한국의 재자원화산업의 개 
吳在賢 $\cdot$ 金俊秀 · 文碩敏 · 閔芝源

관은 후일 한국, 일본 및 대만의 도시광산재자원화산업 을 비교 검토함에 있어서 귀중한 자료가 될 것이다.

\section{2. 도시광산개발의 요건(Key point)}

자연광산개발에 있어서 중요한 요소는 매장량, 품위, 존재형태 및 금속가격 등을 예거할 수 있다. 도시광산 개발의 조건도 자연광산과 대동소이하다. 매장량은 금 속소비량(금속축적량)으로부터 추정할 수 있고 품위는 분석에 의해서 판정할 수 있다. 존재형태에 있어서는 자 연광산의 경우 순금속, 산화물, 황화물, 탄산염물 등으 로 분류할 수 있고 또 이들이 치밀하게 결합되어 단체 분리가 어려운 형태의 것도 있다. 도시광산의 경우는 순 금속, 합금상태(예, 스테인리스), 복잡혼합물(예, 컴퓨터 칩) 및 분산형태(예, 페인트) 등으로 분류할 수 있다. 금속가격은 양자에 미치는 영향이 동일하며 매우 중요 한 요소로 작용한다. 자연광산과 도시광산의 중요한 차 이점 중 하나는 도시광산의 광석(사용후제품)중에는 유 해한 중금속(예, $\mathrm{Pb}, \mathrm{Cd}, \mathrm{Hg}, \mathrm{Be}$ 등)이 함유될 수 있다 는 점이다. 이런 경우는 시장경제원리와 관계없이 자원 으로 회수하든지 또는 무해화처리를 해야 한다. Table 1 은 T.E.Graedel ${ }^{1)}$ 에 의해서 작성된 각종 금속의 용도와 재자원화타당성(recycling potential)을 나타낸 표이다. 이 Table과 금속가격으로부터 도시광산개발의 타당성 (경제성)을 검토할 수 있다.

\section{3. 한국의 금속소비량}

한국의 도시광산자원을 논함에 있어 한국의 금속소비 량을 파악하는 것은 매우 중요하다. 즉 금속소비량이 축 적되어 도시광산자원이 되기 때문이다. Table 2에 한국 의 금속소비량을 나타내었다. 현재(2011.8)까지 공공기 관에서 금속종이 망라된 금속소비량을 발표한 통계자료 는 없는 것으로 알고 있다. Table 2를 작성함에 있어 자료원은 매우 다양하다. 베이스메탈 $(\mathrm{Al}, \mathrm{Cu}, \mathrm{Zn}, \mathrm{Pb})$ 과 $\mathrm{Ni}$ 및 $\mathrm{Sn}$ 은 한국비철금속협회(1)의 내부자료 $(2011)^{2)}$ 에서 인용하였다. $\mathrm{Fe}$ 이외의 6개 금속종 $(\mathrm{Al}, \mathrm{Cu}, \mathrm{Zn}$, $\mathrm{Pb}, \mathrm{Ni}, \mathrm{Sn})$ 은 비철금속협회에서 관리하고 있어 항상 최신자료를 접할 수 있다.

이중 베이스메탈 $\mathrm{Fe}$ 는 한국철강협회(2)에서 매년 출 판하는 “철강통계연보" ${ }^{3)}$ 에서 역시 최신자료(2011)를 접 할 수 있다. 2009년도의 자료는 관세청 HS $\operatorname{code}^{4)} 21$, 28,81 류(수입)(3)에서 수록한 것이다. 국내생산이 없는
금속종은 수입량을 소비량으로 간주하였다. 2007년도 자료는 지식경제부 지원으로 한국비철금속협회가 주관 한 "산업용 원자재 중장기수급 안정화방안 연구(희유금 속을 중심으로)" 연구용역 보고서(4) $)^{5)}$ 에서 인용하였다. 그 외 비철금속생산회사 $(7,8)^{6)}$ 등을 탐방하여 2011년 도 자료(5)를 입수하기도 하였고, 학술대회에서 발표자 료(6)로부터 직접 입수(2011년도)하기도 하였다. 가급적 최신자료와, 정확한 자료를 확보하려고 노력하였지만, Table 2가 완벽한 한국의 금속소비량 통계자료로 신뢰 하기에는 부족한 점이 있을 것으로 안다. 앞으로 많은 관련자가 이 Table 2의 미숙한 점을 수정 보완하여 자 타가 공인하는 도시광산개발에 유익한 금속소비량 통계 자료가 되기를 바란다.

Fig. 1은 한국에 있어서 금속소비량의 순위를 나타낸 것이다. 철이 58,912 천톤으로 가장 많고, 이트륨이 $75 \mathrm{~kg}$ 으로 가장 적다. Fig. 1은 한국의 금속소비량을 거시적 으로 전체상을 파악하기 위해서 그린 것이다.

\section{4. 도시광산 금속 축적량의 추정}

전술한 바와 같이 도시광산 개발 즉 재자원화산업에 있어 금속 축적량은 대단히 중요하고, 이 축적량은 금속 소비량으로부터 추정할 수 있다. 철강통계연보 ${ }^{3)}$ 에 의하 면, 2009년도 철강누계축적량은 522,212천톤으로 되어 있다. 즉 2009년도 철강소비량 47,339천톤의 11 배가 된 다. 이것이 한국에 있어서 유일한 금속축적량 자료이다.

일본에 있어서 철강축적량9)은 $1,200,000$ 천톤이고, 년 간 소비량 ${ }^{10)}$ 은 120,000 천톤이므로 철강축적량은 연간 소비량의 10 배가 된다. 즉 일본과 한국은 철강 연간소 비량의 10-11배의 철강축적량을 가지고 있다. 이러한 맥락과 시나리오로 한국의 도시광산 금속축적량을 작성 하였다. 즉 일본의 각 금속의 도시광산 축적량은 각 금 속 연간소비량의 몇 배인가를 산출하여, 이 배수를 한 국의 해당금속에 적용시켰다.

Table 3은 일본에 있어서 도시광산 금속축적량 $(\mathrm{A})$ 이 연간 금속소비량(B)의 몇 배인가를 비교한 대비표이다. Table 4는 Table 3의 대비표를 참고로 작성한 한국의 금속축적량을 추정한 것이다.

T.E.Graedel ${ }^{1)}$ 은 “The prospects for Urban Mining" 에서 금속축적량은 연간 금속소비량의 약 20 배가 된다 고 말하고 있다. Table 3에서도 평균 배수가 22로 산 출되고 있다. 우연이겠지만 근사한 배수가 나와서 매우 흥미롭다. 
Table 1. Principal uses(by percentage of total use) and recycling potential of metals in the periodic table

\begin{tabular}{|c|c|c|}
\hline Metal & Principal Uses ${ }^{\#}$ & Reference \\
\hline $\mathrm{Li}$ & Batteries $(25, \mathrm{~b})$, glasses $(18, \mathrm{c})$, greases $(12, \mathrm{~d})$ & SQM,2007 \\
\hline $\mathrm{Be}$ & Electronics $(60, \mathrm{c})$, aerospace $(20, \mathrm{c})$, appliances $(10, \mathrm{c})$ & USGS,2010 \\
\hline B & Ceramics $(76, \mathrm{c})$, soaps $(5, \mathrm{~d})$, agriculture $(4, \mathrm{~d})$ & USGS, 2010 \\
\hline $\mathrm{Mg}$ & Refractories $(40, \mathrm{~d})$, chemicals(37,d), Al alloys $(16, \mathrm{~b})$ & USGS,2010* \\
\hline $\mathrm{Al}$ & Transport(28,b), buildings(25,b), electrical(18,a) & IAI,2006 \\
\hline $\mathrm{Sc}$ & $\mathrm{Al}$ alloys(85?,b), lamps(?,b), electrical(?,c) & USGS, 2010 \\
\hline $\mathrm{Ti}$ & Pigments(94,d) aerospace(4,b) & USGS,2010 \\
\hline $\mathrm{V}$ & Steels $(85, \mathrm{~b})$, Ti-Al alloys $(10, \mathrm{~b})$, chemicals $(5, \mathrm{~d})$ & Perron,2001 \\
\hline $\mathrm{Cr}$ & Metal goods $(30, b)$, buildings $(25, b)$, indust. machinery $(25, b)$ & Johnson et al., 2006 \\
\hline $\mathrm{Mn}$ & Steel(6,b), Al alloys $(1, b)$ & Nakajima et al., 2008 \\
\hline $\mathrm{Fe}$ & construction $(45, \mathrm{~b})$, transport $(24, \mathrm{~b})$, indust. machinery $(20, \mathrm{~b})$ & Wang et al.,2007 \\
\hline Co & Superalloys $(49, \mathrm{~b})$, chemicals $(27, \mathrm{c})$, metallurgy $(15, \mathrm{~b})$ & USGS, 2010 \\
\hline $\mathrm{Ni}$ & Stainless steel $(68, \mathrm{~b})$, superalloys $(11, \mathrm{~b})$, plating $(6, \mathrm{~b})$ & Reck et al.,2008 \\
\hline $\mathrm{Cu}$ & $\operatorname{Buildings}(50, \mathrm{a})$, electronics $(21, \mathrm{a}), \operatorname{transport}(11, \mathrm{a})$ & USGS,2010 \\
\hline $\mathrm{Zn}$ & Galvanizing $(55, \mathrm{~b}), \mathrm{Zn}$ alloys(21,b), brass/bronze $(16, \mathrm{~b})$ & USGS,2010 \\
\hline $\mathrm{Ga}$ & Electronics(67,c), optoelectronics(31,c) & USGS, 2010 \\
\hline $\mathrm{Ge}$ & Fiber optics $(35, \mathrm{c})$, infrared optics $(30, \mathrm{c})$, catalysts $(15, \mathrm{c})$ & USGS, 2010 \\
\hline As & Wood preservatives(50,d), batteries(?,d), electronics(?,c) & USGS,2007 \\
\hline $\mathrm{Se}$ & Glass(25,d), metallurgy $(22, b)$, agriculture(19,d) & Kirk-Othmer,2009 \\
\hline $\mathrm{Sr}$ & Pyrotechnics(30,d), magnets(30,b), alloys $(10, \mathrm{~b})$ & USGS,2010 \\
\hline Y & Lighting $(45, \mathrm{c})$, flat panel displays $(33, \mathrm{c})$, glass additives $(12, \mathrm{c})$ & Du and Graedel,2011 \\
\hline $\mathrm{Zr}$ & Ceramics $(54, \mathrm{~d})$, refractories $(13, \mathrm{~d})$, metallurgy $(13, \mathrm{~b})$ & TZ Minerals Int'1,2007 \\
\hline $\mathrm{Nb}$ & Steel(76,b), superalloys $(24, b)$ & USGS, 2010 \\
\hline Mo & Steels $(50, \mathrm{~b})$, stainless steel $(25, \mathrm{~b})$, chemicals $(14, \mathrm{~d})$ & IMOA,2010 \\
\hline $\mathrm{Ru}$ & $\operatorname{Electrical}(59, \mathrm{c})$, chemical $(20, \mathrm{~d})$, electrochemical $(14, \mathrm{c})$ & Butler,2010 \\
\hline $\mathrm{Rh}$ & Autocatalyst $(86, a), \operatorname{chemical}(8, c), \operatorname{glass}(4, c)$ & Butler,2010 \\
\hline $\mathrm{Pd}$ & Autocatalyst(54,a), electrical(17,c), jewelry $(12, c)$ & Butler,2010 \\
\hline $\mathrm{Ag}$ & Industrial(57,c), jewelry $(20, b)$, photography $(16, a)$ & Silver Institute, 2011 \\
\hline $\mathrm{Cd}$ & $\operatorname{Batteries}(83, \mathrm{~b})$, pigments $(8, \mathrm{~d})$, platings $(7, \mathrm{~b})$ & USGS,2009 \\
\hline In & Monitors(33,c), TV $(24, c)$, computers $(15, c)$ & Matos et al.,2005 \\
\hline Sn & $\operatorname{Electrical}(50, \mathrm{~b})$, cans $(18, \mathrm{~b})$, chemicals $(14, \mathrm{c})$ & Tin Technology Ltd.,2006 \\
\hline $\mathrm{Sb}$ & Flame retardant $(40, d)$, transport $(22, b)$, chemicals $(14, c)$ & USGS,2010 \\
\hline $\mathrm{Te}$ & Metallurgy $(60, \mathrm{~b})$, chemicals $(25, \mathrm{~d})$, electrical $(8, \mathrm{c})$ & Kirk-Othmer,2009 \\
\hline $\mathrm{La}$ & Catalysts(30,b), metallurgy $(22, b)$, batteries $(14, b)$ & Du and Graedel,2011 \\
\hline $\mathrm{Ce}$ & Autocatalyst $(35, \mathrm{~b})$, metallurgy $(31, \mathrm{~b})$, glass additives $(16, \mathrm{c})$ & Du and Graedel,2011 \\
\hline
\end{tabular}


Table 1. Continued

\begin{tabular}{|c|c|c|}
\hline Metal & Principal Uses ${ }^{\#}$ & Reference \\
\hline $\operatorname{Pr}$ & Computers $(27, b)$, audio systems $(21, b)$, wind turbines $(12, b)$ & Du and Graedel,2011 \\
\hline $\mathrm{Nd}$ & Computers $(29, b)$, audio systems $(22, b)$, wind turbines $(13, b)$ & $\mathrm{Du}$ and Graedel,2011 \\
\hline $\mathrm{Sm}$ & Defense applications $(70, b)$, batteries $(30, b)$ & Du and Graedel,2011 \\
\hline Eu & Lighting $(50, \mathrm{c})$, flat panel displays $(33, \mathrm{c})$, plasma $(12, \mathrm{c})$ & Du and Graedel,2011 \\
\hline Gd & Computers(32,b), audio systems $(25, b)$, wind turbines $(15, b)$ & Du and Graedel,2011 \\
\hline $\mathrm{Tb}$ & $\operatorname{Lighting}(27, \mathrm{c})$, flat panel displays $(20, \mathrm{c})$, computers $(15, \mathrm{c})$ & Du and Graedel,2011 \\
\hline Dy & Computers $(33, b)$, audio systems $(26, b)$, wind turbines $(15, b)$ & Du and Graedel,2011 \\
\hline Ho & Magnetics $(100, \mathrm{~b})$ & Du and Graedel,2011 \\
\hline Er & Fiber optics(75?,c), lasers(20,c), optical glass(5?,c) & Du and Graedel,2011 \\
\hline $\mathrm{Tm}$ & X-ray(75?c), lasers(20?c), electronics(5?,c) & Du and Graedel,2011 \\
\hline $\mathrm{Yb}$ & X-ray(75?c), lasers(20?c), electronics(5?,c) & Du and Graedel,2011 \\
\hline $\mathrm{Lu}$ & Electronics(80?,c), medical(20?c) & Du and Graedel,2011 \\
\hline $\mathrm{Hf}$ & Superalloys $(40 ?, \mathrm{~b})$, nuclear power(30?,a), electronics(5?,c) & USGS,2009* \\
\hline Ta & Capacitors $(68, \mathrm{c})$, other electronics $(11, \mathrm{c})$, superalloys $(8, \mathrm{~b})$ & Nassar,2010 \\
\hline $\mathrm{W}$ & Cutting tools(60), metallurgy 15 ?,b), superalloys $(10 ?, \mathrm{~b})$ & USGS,2010 \\
\hline $\operatorname{Re}$ & Superalloys $(77, \mathrm{~b})$, catalysts $(15, \mathrm{a})$, crucibles $(8, \mathrm{a})$ & USGS,2008 \\
\hline $\mathrm{Ir}$ & Electrochemicals $(25, \mathrm{c})$, chemical $(21, \mathrm{c})$, electrical $(15, \mathrm{c})$ & Butler,2010 \\
\hline $\mathrm{Pt}$ & Autocatalyst( $46, a)$, jewelry $(26, a)$, chemical $(5, d)$ & Butler,2010 \\
\hline $\mathrm{Au}$ & Jewelry $(72, a)$, electronics $(7, c), \operatorname{dental}(2, b)$ & USGS,2010 \\
\hline $\mathrm{Hg}$ & $\operatorname{Mining}(75 ?, \mathrm{~d})$, medicine(10?,a), lighting(10?,c) & USGS,2010* \\
\hline $\mathrm{Tl}$ & Medicine $(40 ?, \mathrm{~d})$, radiation detection(30?,c) & USGS,2010* \\
\hline $\mathrm{Pb}$ & Batteries $(75, a)$, pipe and sheet $(5, a)$, cable sheathing $(2, a)$ & Mao et al.,2008 \\
\hline $\mathrm{Bi}$ & Metallurgical $(45, \mathrm{~b})$, alloys $(29, \mathrm{~b})$, chemicals $(25, \mathrm{~d})$ & USGS,2010 \\
\hline
\end{tabular}

\#(a) Largely existing or readily recoverable in pure form; (b) largely in multicomponent alloy form; (c) largely in complex assemblages; (d) largely dissipative uses.

*Use percentages are estimated in the present work, based on the cited text information.

\section{5. 한국의 도시광산 재자원화산업}

\section{1. 철의 리싸이클링}

Table $5^{3)}$ 는 최근 5 년간의 조강생산량을 나타낸 것이 다. 2010년 전로(轉盧)에 의한 생산이 34,111,463톤, 전 기로(電氣爐)에 의한 조강생산이 24,800,790톤, 합계 $58,912,253$ 톤이다. 전기로 조업원료는 고철이므로 철스 크랩의 수입과 수출을 고려하지 않는다면, Table 2에서 와 같이 철의 리싸이클링률은 $24,800,790 / 58,912,253=$ $42 \%$ 가 된다. 한편 철스크랩의 수급은 Table $6^{3}$ 과 같다. 철 스크랩의 소비는 전기로 메이커가 주력이고 일부 는 고로 제철 메이커 및 주물 메이커에서 여러 가지
철강제품으로 생산된다. 한국의 전기로 메이커는 (주)포 스코, 현대제철(주)를 위시하여, 동국제강(주), 한국철강 (주), 대한제강(주), 두산중공업(주), 와이케이스틸, 포스 코특수강(주), (주)세아베스틸, 환영철강공업(주), 한국제 강(주), 한국특수형강(주) 및 함양제강(주)의 13 개 회사 가 있다. 이들 회사가 배출하는 제강분진(EAF Dust)이 약 40 만톤/년으로 추정되며 이 제강분진에서 아연(평균 $20 \%$ 함유)의 회수가 추진 중에 있다.

\section{2. $\operatorname{ELV}$ (사용이 끝난 자동차 ) 의 리싸이클링}

5.2.1. 한국 $\mathrm{ELV}$ 리싸이클링의 전체상 $(\text { 소體像 })^{11)}$

Fig. 2에 2009년도 한국의 말소(자진)등록차의 처리흐 
Table 2. Metal consumption in Korea

\begin{tabular}{|c|c|c|c|c|c|c|}
\hline \multicolumn{7}{|c|}{ (a) 베이스메탈(2010) } \\
\hline 종류 & 단위 & 소비량 & 생산량 & 수입량 & 비고 & 자료출처 \\
\hline $\mathrm{Fe}$ & 천톤 & 58,912 & 58,912 & & $\begin{array}{l}\text { 전기로 } 24,800 / 58,912 \\
=42.1 \% \text { 리싸이클링률 }\end{array}$ & (2) \\
\hline $\mathrm{Al}$ & 천톤 & 1,318 & & $\begin{array}{c}\text { 순괴 } 986 \\
\text { 합금계 } 332\end{array}$ & & (1) \\
\hline $\mathrm{Cu}$ & 천톤 & 1,313 & $\begin{array}{c}\text { 전기동 } 20 \text { (고려아연) } \\
\text { 전기동 } 562 \text { (LS-니꼬) } \\
\text { 동스크랩 } 350\end{array}$ & $\begin{array}{l}\text { 전기동 } 332 \\
\text { 동스크랩 } 49\end{array}$ & $\begin{array}{c}350 / 1,313=26.6 \% \\
\text { 리싸이클링률 }\end{array}$ & (1) \\
\hline $\mathrm{Zn}$ & 천톤 & 815 & 734 & 81 & $\begin{array}{c}\text { 생산능력 : } \\
\text { 영풍 } 300, \text { 고려아연 } 450\end{array}$ & (1) \\
\hline $\mathrm{Pb}$ & 천톤 & 321 & $\begin{array}{l}\text { 전기연 } 191 \\
\text { 재생연 } 130\end{array}$ & & $\begin{array}{c}130 / 321=40.5 \% \\
\text { 리싸이클링률 }\end{array}$ & (1) \\
\hline
\end{tabular}

(b) 독성이 강한 레어메탈(2009)

\begin{tabular}{|c|c|c|c|c|c|c|}
\hline $\mathrm{Sb}$ & 톤 & $\begin{array}{c}21,000 \text { ( } \mathrm{Sb} \text { 금속 및 } \\
\mathrm{Sb} \text { 산화물로 추정, 2007) }\end{array}$ & 고려아연 $\mathrm{Sb}_{2} \mathrm{O}_{3} 600$ 톤 & $6,165(2009)$ & $\mathrm{Sb}_{2} \mathrm{O}_{2}$ 수입량 3,420톤(2009) & (3)(4)(5) \\
\hline $\mathrm{Cd}$ & 톤 & 3,000 & 3,000 톤(고려아연) & $639(2009)$ & & $(3)(5)$ \\
\hline $\mathrm{As}$ & 톤 & & & & & \\
\hline $\mathrm{Se}$ & 톤 & 400 & 400 톤(LS-Nikko) & & & $(5)$ \\
\hline $\mathrm{Hg}$ & 톤 & & & & & \\
\hline $\mathrm{Be}$ & 톤 & $10(2007)$ & & 4.0 & & $(4)$ \\
\hline
\end{tabular}

(c) 고가이고 역사가 있는 레어메탈(2010)

\begin{tabular}{|c|c|c|c|c|c|c|}
\hline $\mathrm{Ag}$ & 톤 & 2,009 & $\begin{array}{c}\text { LS-Nikko } 600 \\
\text { 고려아연 } 1,290\end{array}$ & 89.3 & 스크랩 30 & (5) \\
\hline $\mathrm{Au}$ & 톤 & 105.3 & $\begin{array}{c}\text { LS-Nikko } 50.6 \\
\text { 고려아연 } 2.7\end{array}$ & $\begin{array}{c}\text { 수입 } 12 \\
\text { 수출 } 35\end{array}$ & 스크랩 40 & (5) \\
\hline $\mathrm{Pt}$ & 톤 & $30(2007)$ & $\begin{array}{l}\text { LS-Nikko } 0.36 \\
\text { 고려아연 } 0.002\end{array}$ & & & (4)(5) \\
\hline
\end{tabular}

\begin{tabular}{|c|c|c|c|c|c|c|}
\hline \multicolumn{7}{|c|}{ (d) 기타 레어메탈 } \\
\hline $\mathrm{Si}$ & 천톤 & 금속 400 & & & $\begin{array}{c}\text { 수요 금속합금 } 40 \text { 만톤, } \\
\text { 화합물 } 130 \text { 만톤 }\end{array}$ & (4) \\
\hline $\mathrm{Cr}$ & 톤 & 455,000 & - & $1,746(2009)$ & & (3)(4) \\
\hline $\mathrm{Mn}$ & 톤 & $\mathrm{Mn}$ 광석 520,000 & - & $57,683(2009)$ & $\begin{array}{c}\mathrm{MnO}_{2} \text { 수입 (2009) } \\
\text { 6,238톤 }\end{array}$ & (3)(4) \\
\hline $\mathrm{Ni}$ & 톤 & $\begin{array}{c}79,635 \\
(2010) \\
\text { (Ni base) }\end{array}$ & $\begin{array}{c}\text { 유틸리티 13,300 } \\
\text { FeNi } 150,000\end{array}$ & $\begin{array}{l}\mathrm{Ni} \text { 괴 } 34,014 \\
\text { FeNi } 21,014\end{array}$ & $\begin{array}{c}\text { 코리아니켈 } 32,000, \\
\text { 에너텍 } 6,000, \\
\mathrm{SNNC}(\mathrm{FeNi}) 150,000 \\
\text { (Ni base } 30,000 \text { ) }\end{array}$ & $(1)(5)$ \\
\hline REE & 톤 & 22 & & $22(2009)$ & & (3) \\
\hline $\mathrm{Ti}$ & 톤 & $\begin{array}{c}\mathrm{TiO}_{2} \\
100,000(2006) \\
\mathrm{Ti} \text { 금속 } 8,000 \text { 톤 }\end{array}$ & - & 7,439(2009) & $\begin{array}{c}\mathrm{TiO}_{2} \text { 수입(2009) } 8,255 \text { 톤 } \\
\mathrm{Ti} \text { 광과 그 정광 } \\
\text { 수입(2009) } 120,466\end{array}$ & $\begin{array}{l}(3)(4) \\
(6)\end{array}$ \\
\hline
\end{tabular}
(1) 한국비철금속협회(2011) 내부자료
(2) 한국철강협회(2011) 철강통계연보
(4) 연구보고서(2007)
(3) 관세청(2009) HS code $21,28,81$ 류(수입)
(5) 생산회사(2011)
(6) 학회발표자료(2011) 재료마당(2011) Vol.24, No.4, p.104 
Table 2. Continued

\begin{tabular}{|c|c|c|c|c|c|c|}
\hline \multicolumn{7}{|c|}{ (d) 기타 레어메탈 } \\
\hline 종류 & 단위 & 소비량 & 생산량 & 수입량 & 비고 & 자료출처 \\
\hline Sn & 톤 & $18,068(2010)$ & 삼화비철공업 50 톤 & 18,068 & & (1) \\
\hline $\mathrm{Sr}$ & 톤 & & & & & \\
\hline Mo & 톤 & 9,000 (2010) (Mo base) & $\begin{array}{l}\text { 광양합금철 } \mathrm{FeMo} 4,800 \text { 톤 } \\
\text { 삼정피앤에이 } \mathrm{FeMo} 710 \text { 톤 }\end{array}$ & 988 & \begin{tabular}{|c|} 
FeMo 15,000 소비 $(2010)$ \\
$\mathrm{Mo}$ 광과 그 정광수입 11,771 톤 \\
$\mathrm{MoO}_{3}$ 수입(2009) 125 톤
\end{tabular} & (3)(5) \\
\hline $\mathrm{B}$ & 톤 & & & & & \\
\hline Co & 톤 & $5,700(2007)$ & $\begin{array}{l}\text { 고려아연 220톤 } \\
\text { (Co cake)Co:40\% }\end{array}$ & $1,190(2009)$ & & $(3)(4)(5)$ \\
\hline $\mathrm{Zr}$ & 톤 & $1,700(2007)$ & - & $355(2009)$ & & $(4)(3)$ \\
\hline W & 톤 & $\begin{array}{l}6,000(2007) \\
(\mathrm{W} \text { base })\end{array}$ & - & $343(2009)$ & $\begin{array}{c}\mathrm{W} \text { 광과 그 정광수입 406톤 } \\
\mathrm{WO}_{3} \text { 수입(2009) 2,000톤 } \\
\end{array}$ & (3)(4) \\
\hline V & 톤 & $11,453(2007)$ & - & $1.0(2009)$ & $\begin{array}{c}\text { 산화바나듐 및 수산화바나듐 } \\
\text { 수입(2009) 2,354톤 }\end{array}$ & (3)(4) \\
\hline $\mathrm{Nb}$ & 톤 & $4,000(2007)$ & - & $7.0(2009)$ & & $(3)(4)$ \\
\hline $\mathrm{Li}$ & 톤 & 19,557 & & $\begin{array}{c}\text { 산화리튬(2009) } \\
19,557\end{array}$ & & (3) \\
\hline $\mathrm{Bi}$ & 톤 & 1,000 & 고려아연 500 톤 & $500(2009)$ & $\begin{array}{c}\text { LS-Nikko Bi cake } 30 \\
\mathrm{Bi}>25 \%\end{array}$ & $(3)(5)$ \\
\hline In & 톤 & $482(2010)$ & $482(2010)$ & $\begin{array}{c}57(2009) \\
378(2007)\end{array}$ & $\begin{array}{c}\text { 2010년 토리컴 } 100, \\
\text { ICK } 120 \text {, 고려아연 } 250, \\
\text { 나인디지트 } 12 \text { 생산 }\end{array}$ & $(3)(5)$ \\
\hline Ta & 톤 & $\begin{array}{l}110 \sim 150 \\
(2011)\end{array}$ & & & $\begin{array}{c}\text { 금속 70-80톤, } \\
\text { Ta target 20-30톤, } \\
\text { 업체 자체수입 10-20톤, } \\
\text { 합계 약 } 110-150 \text { 톤 } \\
\end{array}$ & $(5)(6)^{8)}$ \\
\hline $\mathrm{Ga}$ & 톤 & 13 & $\begin{array}{c}\text { 고려아연 } 7 \text { 톤 } \\
\text { 나인디지트 } 6 \text { 톤 }\end{array}$ & & & (5) \\
\hline $\mathrm{Te}$ & 톤 & $1,500(2007)$ & $\begin{array}{c}\text { LS-니꼬 } 30 \text { 톤, } \\
\text { 고려아연(Te oxide)23톤 } \\
\text { 생산(2010) }\end{array}$ & & & (5) \\
\hline $\mathrm{Ge}$ & 톤 & $44 \mathrm{~kg}$ & 고려아연 $500 \mathrm{~kg}$ & $44(2009)$ & 산화게르마늄 수입(2009) 7톤 & $(3)(5)$ \\
\hline $\mathrm{Pd}$ & $\mathrm{kg}$ & 2,320 & $\begin{array}{c}\text { LS-Nikko } 2,300 \mathrm{~kg} \\
\text { 고려아연 } 20 \mathrm{~kg}\end{array}$ & & & (5) \\
\hline $\mathrm{Hf}$ & 톤 & & & & & \\
\hline $\mathrm{Mg}$ & 톤 & 27,195 & 8,840 (스크랩) & $\begin{array}{l}\text { Mg ingot } 9,500 \\
\text { Mg Alloy } 6,200 \\
\quad \text { 기타 2,655 } \\
\end{array}$ & $\begin{array}{l}8,840 /(8,840+18,355)= \\
32.5 \% \text { 리싸이클링률 }\end{array}$ & $(6)^{7)}$ \\
\hline $\mathrm{Nd}$ & 톤 & $6,000(2007)$ & & & & (4) \\
\hline $\mathrm{Ce}$ & $\mathrm{kg}$ & 19,301(2009) & & 19,301(2009) & & (3) \\
\hline $\mathrm{Eu}$ & $\mathrm{kg}$ & $504(2009)$ & & $504(2009)$ & & (3) \\
\hline $\mathrm{Y}$ & $\mathrm{kg}$ & $75(2009)$ & & $75(2009)$ & & (3) \\
\hline $\mathrm{Sc}$ & $\mathrm{kg}$ & $757(2009)$ & & $757(2009)$ & & (3) \\
\hline
\end{tabular}
(1) 한국비철금속협회(2011) 내부자료
4) 연구보고서(2007)
(2) 한국철강협회(2011) 철강통계연보
(5) 생산회사(2011)
(3) 관세청(2009) HS code $21,28,81$ 류(수입)
(6) 학회발표자료(2011)

J. of Korean Inst. Resources Recycling Vol. 20, No. 6, 2011 


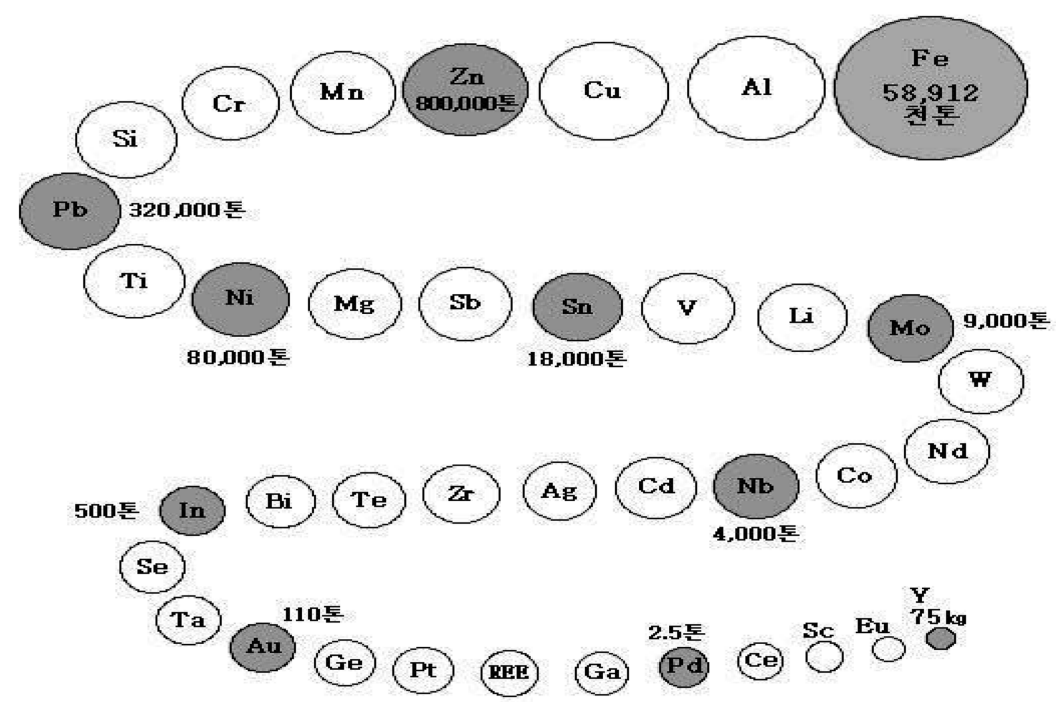

Fig. 1. The order of the metal consumption in Korea.

Table 3. The comparison with the metal stock reserves(A) to the annual metal consumption(B) in Japan

\begin{tabular}{|c|c|c|c|c|}
\hline & 단위 & A & B & $\mathrm{A} / \mathrm{B}$ \\
\hline $\mathrm{Fe}$ & 천톤 & $1,200,000$ & 120,000 & 10 \\
\hline $\mathrm{Al}$ & 천톤 & 85,000 & 4,400 & 19.3 \\
\hline $\mathrm{Cu}$ & 천톤 & 70,000 & 1,250 & 56 \\
\hline $\mathrm{Cr}$ & 천톤 & 25,000 & 630 & 40 \\
\hline $\mathrm{Zn}$ & 천톤 & 11,000 & 650 & 17 \\
\hline $\mathrm{Pb}$ & 천톤 & 8,000 & 300 & 26 \\
\hline $\mathrm{Ni}$ & 천톤 & 7,000 & 236 & 29 \\
\hline Sn & 톤 & 800,000 & 36,000 & 22 \\
\hline $\mathrm{Re}$ & 톤 & 600,000 & 40,000 & 15 \\
\hline Mo & 톤 & 300,000 & 27,700 & 1 \\
\hline $\mathrm{Li}$ & 톤 & 200,000 & 3,468 & 57 \\
\hline V & 톤 & 150,000 & 6,400 & 23 \\
\hline Co & 톤 & 150,000 & 14,500 & 10 \\
\hline $\mathrm{Ag}$ & 톤 & 80,000 & 4,490 & 18 \\
\hline W & 톤 & 80,000 & 9,600 & 8 \\
\hline $\mathrm{Au}$ & 톤 & 8,000 & 280 & 28 \\
\hline Ta & 톤 & 7,000 & 629 & 1 \\
\hline $\mathrm{Pt}$ & 톤 & 5,000 & 32.5 & 15 \\
\hline In & 톤 & 2,000 & 905 & 2 \\
\hline \multicolumn{2}{|c|}{ 평균 } & & & 22 \\
\hline
\end{tabular}

Table 4. The metal stock reserves from the Urban mine in Korea (estimation)

\begin{tabular}{|c|c|c|c|c|}
\hline & 단위 & $\begin{array}{c}\text { 연간 금속 } \\
\text { 소비량 }\end{array}$ & 배수 & $\begin{array}{c}\text { 추정 금속 } \\
\text { 축적량 }\end{array}$ \\
\hline $\mathrm{Fe}$ & 천톤 & 58,912 & 10 & 589,120 \\
\hline $\mathrm{Al}$ & 천톤 & 1,318 & 19.3 & 25,437 \\
\hline $\mathrm{Cu}$ & 천톤 & 1,313 & 56 & 73,528 \\
\hline $\mathrm{Cr}$ & 천톤 & 815 & 17 & 13,855 \\
\hline $\mathrm{Zn}$ & 천톤 & 455 & 40 & 18,200 \\
\hline $\mathrm{Pb}$ & 천톤 & 321 & 26 & 8,346 \\
\hline $\mathrm{Ni}$ & 천톤 & 79.635 & 29 & 2,309 \\
\hline Sn & 톤 & 18,068 & 22 & 397,496 \\
\hline V & 톤 & 11,453 & 23 & 263,419 \\
\hline $\mathrm{Li}$ & 톤 & 19,557 & 57 & $1,114,749$ \\
\hline Mo & 톤 & 9,000 & 11 & 99,000 \\
\hline W & 톤 & 6,000 & 8 & 48,000 \\
\hline $\mathrm{Co}$ & 톤 & 5,700 & 10 & 57,000 \\
\hline $\mathrm{Ag}$ & 톤 & 2,009 & 18 & 36,162 \\
\hline In & 톤 & 482 & 2 & 964 \\
\hline $\mathrm{Ta}$ & 톤 & 150 & 11 & 1,650 \\
\hline $\mathrm{Au}$ & 톤 & 105 & 28 & 2,940 \\
\hline $\mathrm{Pt}$ & 톤 & 30 & 15 & 450 \\
\hline $\operatorname{Re}$ & 톤 & 22 & 15 & 330 \\
\hline
\end{tabular}

자원리싸이클링 제 20 권 제 6 호, 2011 
Table 5. Production of crude steel

\begin{tabular}{|c|c|c|c|c|c|c|c|}
\hline \multirow{2}{*}{} & \multicolumn{3}{|c|}{ 전로 } & \multicolumn{2}{c|}{ 전기로 } & 합계 \\
\cline { 2 - 8 } & 특수강 Specialty & 보통강 Ordinary & B.O.F. & 특수강 Specialty & 보통강 Ordinary & E.A.F. & Total \\
\hline 2010 & $2,256,309$ & $31,855,154$ & $34,111,463$ & $4,797,107$ & $20,003,683$ & $24,800,790$ & $58,912,253$ \\
\hline 2009 & $1,496,333$ & $26,170,583$ & $27,666,916$ & $3,781,895$ & $17,123,463$ & $20,905,358$ & $48,572,274$ \\
\hline 2008 & $2,680,193$ & $27,546,375$ & $30,226,568$ & $4,709,120$ & $18,689,242$ & $23,398,362$ & $53,624,930$ \\
\hline 2007 & $2,877,992$ & $24,682,962$ & $27,560,954$ & $4,926,825$ & $19,029,530$ & $23,956,355$ & $51,517,309$ \\
\hline 2006 & $1,658,061$ & $24,632,946$ & $26,291,007$ & $4,699,675$ & $17,464,772$ & $22,164,447$ & $48,455,454$ \\
\hline
\end{tabular}

Table 6. Demand and supply of Fe scrap

(단위 : MT)

\begin{tabular}{|c|c|c|c|c|c|}
\hline 년도 & 내수 (Apparent Consumption) & 수출 (Exports) & 총수요 (Total Demand) & 생산1) (Production) & 수입 (Imports) \\
\hline 2010 & $30,496,786$ & 457,695 & $30,954,481$ & $22,864,786$ & $8,089,695$ \\
\hline 2009 & $27,084,194$ & 479,738 & $27,563,932$ & $19,763,512$ & $7,800,420$ \\
\hline 2008 & $29,089,726$ & 369,491 & $29,459,217$ & $22,144,620$ & $7,314,597$ \\
\hline 2007 & $29,386,338$ & 213,177 & $29,599,515$ & $22,715,502$ & $6,884,013$ \\
\hline 2006 & $25,836,364$ & 321,698 & $26,158,062$ & $20,537,900$ & $5,620,162$ \\
\hline
\end{tabular}

(주) 1) 생산은 국내구입 및 자가발생 철 스크랩의 합계

름을 도시하였다. 2009년도의 말소등록대수는 965천대 이다. 이중 264 천대(말소등록 차량의 약 $27 \%$ )가 중고 차로서 수출되었으므로 701천대가 해체장에서 폐차되었 다. 평균 차량중량이 $1,110 \mathrm{~kg}$ 이므로 2009년도는 701천 대 $\times 1.11$ 톤 $=778.1$ 천톤의 $\mathrm{ELV}$ 가 처리된 셈이다.

해체장에서는 여러 가지 액체와 프레온가스를 회수 혹은 제거한 다음 1 대당 재사용부품 $294 \mathrm{~kg}$ 과 재활용물 질 $186.8 \mathrm{~kg}$ 을 회수한다. 즉 해체단계에서 206천톤의 재사용부품과 131 천톤의 재활용물질 ${ }^{12)}$ 이 회수된다.

해체가 완료된 차피 $(616.7 \mathrm{~kg})$ 는 슈레더 처리되어 금 속류 $(445.4 \mathrm{~kg})$ 및 $\mathrm{ASR}(171.3 \mathrm{~kg})$ 로 선별된다. 즉 312.2 천톤의 재활용물질이 회수되고, ASR은 $50 \%$ 가 매 립되며, $50 \%$ 가 시멘트공장에서 에너지로 회수 된다.

또한, 해체단계 및 슈레딩에서는 자동차 구성성분을 참고로 2009년도의 $\mathrm{ELV}$ 로부터

- 철

- 알루미늄

- 구리

의 회수가 이론적으로 산출된다.

$\mathrm{ELV}$ 리싸이클링률의 산출은 매립처분량으로부터 계 산 즉, $95 \%$ 의 리싸이클링률의 달성은 매립 처분량을 $5 \%$ 이내로 한다는 것과 같은 의미로 해석해도 좋다는
견해도 있다. 이 해석의 조건은 $\mathrm{ASR}$ 이외의 $\mathrm{ELV}$ 구 성물품은 $100 \%$ 재사용 또는 재활용하고 있다고 가정한 것이다. 현 해체시스템에서 이 가정이 수긍되는 것도 사 실이다. 한편, 자동차용으로 사용되는 원재료의 추이 ${ }^{13)}$ 로부터 철강재 $73.0 \%$, 비철금속 $7.8 \%$, 합계 $80.8 \%$ 가 회수되고, 고무(타이어) $4.5 \%$, 유리 $1.0 \%$ (도어유리 두 짝), 액류 $1.0 \%$ 및 범퍼회수 등을 고려할 때 Reuse + Recycle 이 $85 \%$ 가 초과할 것이 분명하다. 2009년말 현재 444개의 ELV해체업체와 2010년말 현재 12개의 슈레딩업체가 한국의 자동차리싸이클링산업을 담당하고 있다.

\subsection{2. 중고차 수출}

Table 7은 중고차 수출 일람표이다. 수출대수, 수출금 액, 1대당 수출금액, 수출국가수 및 1,000 대 이상 수출 한 국가수를 표시하였다. 2009년도의 중고차 전체의 수 출금액은 13억 6천만불을 넘어서고, 2003년도의 약 3 배가 되고 1 대당 수출금액도 2.4 배가 되었다. 수출국가 수도 증가추세에 있다.

\subsection{3. 자동차리싸이클링의 경제적 가치}

Fig. 2에서 자동차 폐차처리 시 논술한 바와 같이 철 567천톤, 알루미늄 46.7천톤, 구리 7.7천톤의 발생이 추 
Table 7. The overview of used cars exported in Korea

\begin{tabular}{|c|c|c|c|c|c|c|c|}
\hline 구분 & 2003 & 2004 & 2005 & 2006 & 2007 & 2008 & 2009 \\
\hline 수출대수 & 217,066 & 312,181 & 199,333 & 202,452 & 217,559 & 267,559 & 264,742 \\
\hline 수출금액(천불) & 465,870 & 767,680 & 735,230 & 707,530 & 773,242 & $1,175,265$ & $1,362,047$ \\
\hline 1대당 수출금액(\$) & 2,146 & 2,459 & 3,688 & 3,495 & 3,562 & 4,392 & 5,145 \\
\hline 수출국가수 & - & - & - & - & 126 & 132 & 145 \\
\hline 1,000 대이상 수출국가수 & - & - & - & - & 24 & 25 & 26 \\
\hline
\end{tabular}

주 : 관세청자료를 인용해서 필자가 작성

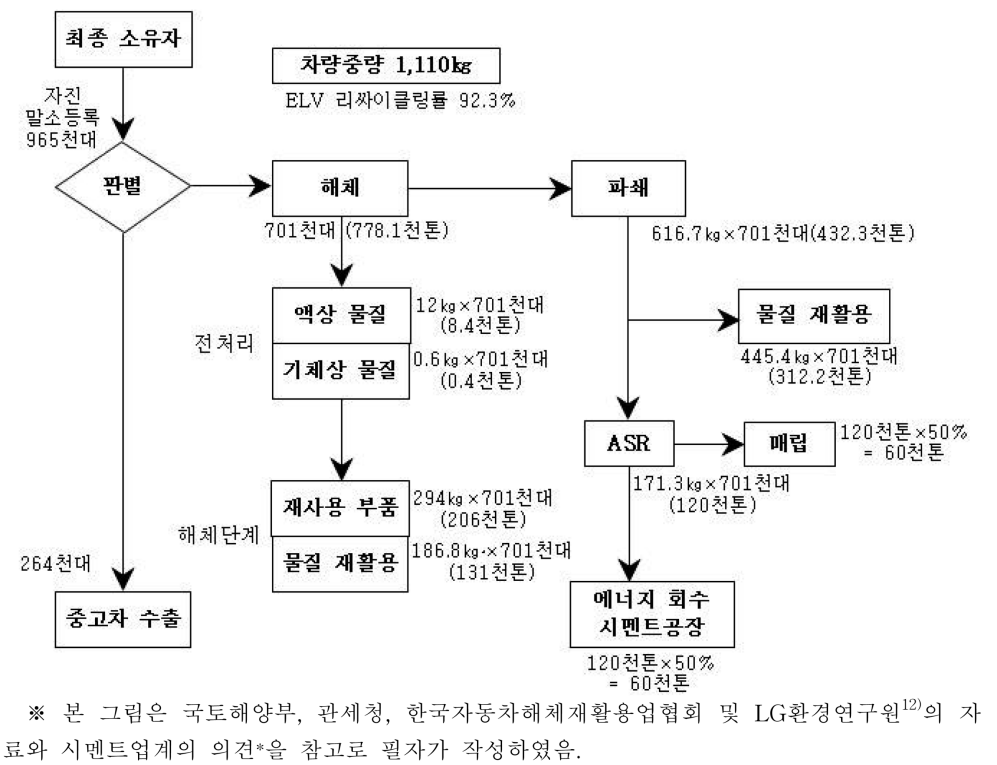

Fig. 2. The overview of processing flow and recycling rate of ELV in Korea(2009).

정된다. 이들의 경제적 가치(2011년 7월의 LME가격 및 환율 1,060 원 적용)는

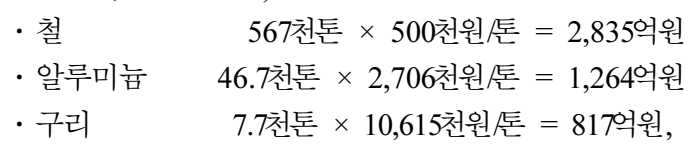

합계 4,916억원으로 추산된다.

그리고 해체시 철의 경제적가치와 동등한 금액의 재 사용부품을 회수 판매한다고 가정하면, $\mathrm{ELV}$ 의 해체 · 슈레딩에서 7,751억원의 매출고를 추정할 수 있다. 한 편, Table 7에 의하면 2009년도 중고차 수출금액은 $1,362,047$ 천불( 1 조 4,438 억원)이다. 위의 양자를 합하면
$\mathrm{ELV}$ 리싸이클링시 발생하는 총 경제적 가치는 년간 약 2조 2천억원으로 추산된다.

\subsection{E-waste 의 리싸이클링 ${ }^{14)}$}

Fig. 3은 2009년도 E-waste(법정) 물질흐름을 도시한 것이다. Fig. 3 에 의해서 다음 사항들을 알 수 있다.

(1) 생산자에 의한 E-waste 재활용량 $(63,627$ 톤 $+51,974$ 톤)은 115,601 톤으로, 소비자 배출량의 $25.9 \%$ 에 해당된 다. 즉 생산자는 배출량의 $25.9 \%$ 만을 재활용하고 있고 생산자재활용책임제도 안에서 운영됨을 알 수 있다.

(2) 제품 소매시 무료로 회수된 E-waste는 $82.6 \%$ 만이 $\mathrm{R} / \mathrm{C}$ (생산자리싸이클링센터) 및 계약리싸이클링업자에게 


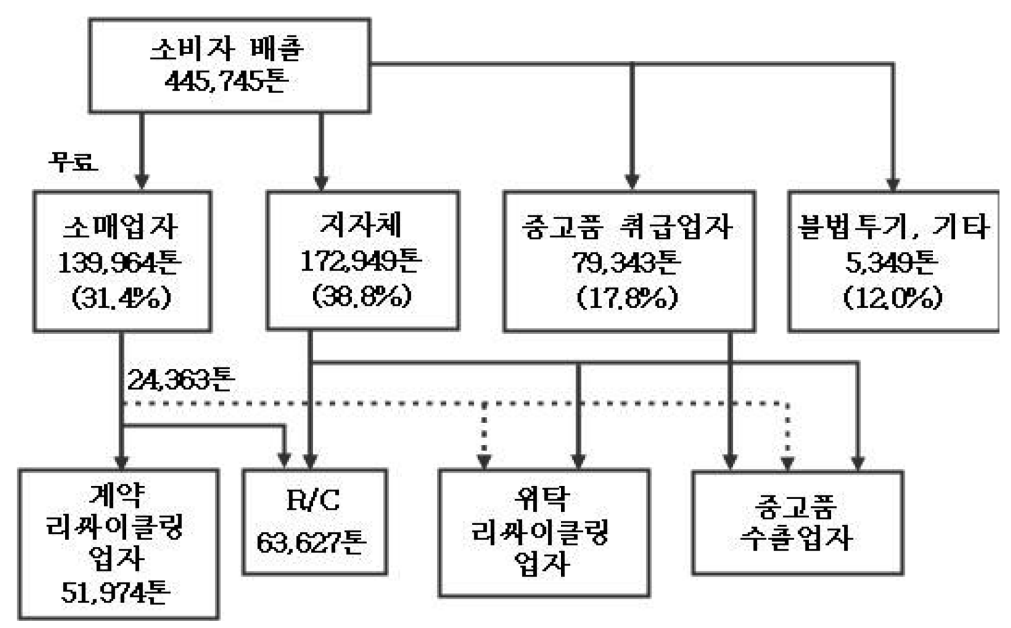

Fig. 3. Material flow of the E-waste(2009).

공급되고 $17.4 \%(24,363$ 톤 $)$ 는 위탁리싸이클링과 중고품 수출업자에게도 수급되고 있다.

(3) 소비자가 배출한 E-waste는 지자체에서 유료로 회

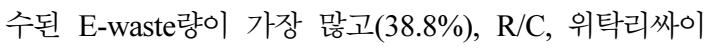
클링업자 및 중고품수출업자에게 수급량으로 이어진다.

(4) E-waste의 눈에 보이는 투명한 흐름은 $25.9 \%$ 에 불과하고, $74.1 \%$ 가 통계가 집계되지 않는 흐름에 의해 유통되고 있다. 특히 지자체 이후의 흐름이 불명료하다. 다만 중고컴퓨터 6,243 톤이 수출된 것으로 확인되고 (Table 9), 2006년 기준으로 휴대전화 수거량의 $37.9 \%$ 가 수출된 것으로 추정 ${ }^{15)}$ 하고 있다.

Table 8은 법정 E-waste의 품목별 출고량, 재활용 의무량 및 실적량을 나타낸 것이다. 법정 10 개 품목의 총 재활용실적량(2009)은 115,601 톤으로 모든 품목에서 의무량을 초과달성하고 있다.

Table 9는 2008년도와 2009년도 E-waste 재료별 재 자원화량을 표시한 것이다. 전체 재자원화량(2009년도) 100,733 톤 중 고철이 45,511 톤으로 $45 \%$, 합성수지가 $24.7 \%$, 비철이 약 $6.5 \%$ 를 차지하고 있다. 재활용실적량 (2009)이 115,601 톤이었으므로 약 $87 \%$ 의 물질이 회수 되었고, 약 15,000 톤의 최종잔재물이 발생했음을 시사 하고 있다.

이들 재활용 물질들은 법정 E-waste의 $26 \%$ 에 해당 되는 재활용량이고 제도 밖(비 법정)의 E-waste의 재활 용량까지 포함한다면 더욱 많은 재활용량을 추산할 수 있다. E-waste의 재자원화산업은 44개의 한국전자산업 환경협회 산하의 협력업체(수집, 분쇄, 선별)와 역시 40 여개의 한국도시광산협회 산하 비철제련업체가 담당하
고 있다. 이 도시광산협회 회원 중에는 LS-Nikko동제 련(주), 고려아연(주)와 같은 대기업 제련회사도 가입되 어 있고 오랫동안 귀금속 추출 제련을 개발한 희성피엠 텍(주)와 애강리메텍(주)도 포함되어 있다.

\section{4. 사업장폐기물의 리싸이클링}

5.4.1. 석유탈황 폐촉매 ${ }^{16)}$

석유 정제공정에서 대량으로 발생하고 있는 탈황폐촉 매는 유가금속의 함량이 높아 재활용의 대상이 되고 있 다. 폐촉매에는 촉매 자체성분 금속 $(\mathrm{Ni}, \mathrm{Mo}, \mathrm{Co}, \mathrm{W})$ 외에도 원유에 포함되어 있는 $\mathrm{V}, \mathrm{Ni}$ 및 $\mathrm{Fe}$ 등이 침적 되어 상당량의 중금속을 함유하고 있다. Table 10에 직 접탈황 및 간접탈황 폐촉매의 평균적인 성분 조성 예를 나타내었다.

국내 정유사들 대부분은 석유 수급 구조의 경질화 및 석유제품의 저유황화 추세에 대처하기 위해 최근 중질 유 분해 및 탈황설비를 도입하여 가동 중에 있다. 중질 유 경질화의 주공정은 상압잔사유 수소화탈황공정(AR$\mathrm{HDS})$, 감압잔사유 수소화탈황공정(VR-HDS), 잔사유 유 동접촉분해공정(R-FCC), 등-경유 수소화분해공정(VGO$\mathrm{HC)}$ 등이 있다. Table 11에 국내 중질유 경질화 공정에 서 발생되는 폐촉매의 양을 연도별로 요약 정리하였다. 우리나라에서는 2005년부터 $\mathrm{V}, \mathrm{Mo}$ 가격의 폭등에 따라 일부 기업들이 폐촉매에서 $\mathrm{V}, \mathrm{Mo}$ 를 회수하는 사 업에 관심을 가지기 시작했다. 2005년에 (주)범아가 중 국에서 기술을 도입하여 이 사업을 시작하였으나 다우 메탈이 이 공장을 인수하여 조업 중이다. 비슷한 시기 에 영신금속도 폐촉매에서 $\mathrm{V}, \mathrm{Mo}$ 를 회수하는 사업을 
Table 8. Amount for domestic market of the EEE and amount for due recycling and recycling practice of the WEEE (단위 : 톤)

\begin{tabular}{|c|c|c|c|c|c|}
\hline 년도 & 품목 & 출고량 & 의무량 & 실적량 & 비고 \\
\hline \multirow{11}{*}{2008} & 냉장고 & 230,795 & 43,620 & 53,555 & $123 \%$ \\
\hline & 세탁기 & 79,760 & 20,179 & 22,035 & $109 \%$ \\
\hline & 에어컨 & 117,706 & 2,438 & 2,432 & $100 \%$ \\
\hline & TV & 95,108 & 13,791 & 19,538 & $142 \%$ \\
\hline & 컴퓨터 & 226,789 & 8,569 & 10,022 & $117 \%$ \\
\hline & 오디오 & 16,642 & 892 & 1,174 & $132 \%$ \\
\hline & 이동전화단말기 & 3,154 & 566 & 721 & $127 \%$ \\
\hline & 프린터 & 10,999 & 1,232 & 1,232 & $100 \%$ \\
\hline & 복사기 & 3,806 & 488 & 497 & $102 \%$ \\
\hline & 팩시밀리 & 721 & 82 & 111 & $135 \%$ \\
\hline & 합계 & 785,480 & 91,857 & 111,317 & $121 \%$ \\
\hline \multirow{11}{*}{2009} & 냉장고 & 211,000 & 43,526 & 56,777 & $130 \%$ \\
\hline & 세탁기 & 95,381 & 24,894 & 26,046 & $105 \%$ \\
\hline & 에어컨 & 126,000 & 2,887 & 2,887 & $100 \%$ \\
\hline & $\mathrm{TV}$ & 73,676 & 11,788 & 18,544 & $157 \%$ \\
\hline & 컴퓨터 & 42,700 & 4,920 & 8,312 & $169 \%$ \\
\hline & 오디오 & 3,974 & 616 & 685 & $111 \%$ \\
\hline & 이동전화단말기 & 3,177 & 629 & 629 & $100 \%$ \\
\hline & 프린터 & 8,255 & 982 & 1,181 & $120 \%$ \\
\hline & 복사기 & 3,179 & 423 & 423 & $100 \%$ \\
\hline & 팩시밀리 & 462 & 56 & 117 & $209 \%$ \\
\hline & 합계 & 567,804 & 90,721 & 115,601 & $127 \%$ \\
\hline
\end{tabular}

시작했으며, 2007년에는 (주)EG와 (주)유니온도 이 사 업에 뛰어 들었다. 국내에서 조업 중인 폐촉매로부터 유 가금속 회수 공정의 개요를 Fig. 4에 나타내었다.

국내 폐촉매 처리업체의 처리능력은 폐촉매의 종류와 상태에 따라 약간씩 차이가 있으나 대략적으로 GS에코메 탈(구, 다우메탈) 7,000톤/년, 영신금속 8,000톤/년, (주)EG 9,000 톤/년, (주)유니온 11,000 톤/년으로 합계 3 만5,000톤 의 처리능력을 보유하게 되었다. 이는 국내에서 발생하는 폐촉매 16,000 톤/년을 상회하는 처리능력으로서 당분간 은 국내 기업 간의 경쟁이 치열할 것으로 예상된다.

한편, 금속 함량이 낮은 유동접촉분해촉매 $(\mathrm{FCC})$ 의 경 우 주성분이 상대적으로 저부가가치의 광물인 $\mathrm{Al}_{2} \mathrm{O}_{3}$ 와 $\mathrm{SiO}_{2}$ 로 되어 있어 부가가치를 창출하기 어려워 전량 매 립하였으나, 1999년 (주)유니온이 시멘트 제조시 첨가물 로 사용하기 시작하면서 재활용이 가능하게 되었으며, 현
재는 각 시멘트 회사에서 이 촉매의 배출량 전체를 재 활용하고 있다.

5.4.2. 전기로 제강분진(EAF Dust $)^{17)}$

전술(철의 리싸이클링)한 바와 같이 우리나라에는 전 기로 제강법에 의하여 $24,800,790$ 톤의 철강을 생산하고 있다(2010년). 이때 제강 톤당 약 $15 \mathrm{~kg}$ 의 분진이 발생 (Fig. 5 참조)하므로 약 37 만톤/년의 분진이 발생하고 있다. 이 분진 중에는 약 $20 \%$ 의 아연(Table 12)이 함 유되어 있고 $\mathrm{Pb}, \mathrm{Cr}, \mathrm{Cl}$ 등의 유해성분이 함유되어 있 으나, 현재 매립 및 Ascon의 충진제 등으로 처리되고 있어 매우 안타까운 실정이다.

만일에 이 EAF Dust를 일본 혹은 대만과 같이 리 싸이클링시에는 약 7 만톤 $(1,700$ 억원 상당)의 아연을 매 년 회수할 수 있고, 환경오염을 방지할 수 있다. 시기적 
Table 9. Amount of the recycling materials from the E-waste

(단위 : 톤)

\begin{tabular}{|c|c|c|c|c|c|c|c|c|c|}
\hline \multirow{2}{*}{ 년도 } & \multirow{2}{*}{ 품목 } & \multicolumn{8}{|c|}{ 재자원량 } \\
\hline & & 재사용 부품 & 고철 & 알루미늠 & 기타 비철 & 합성수지 & 유리 & 기타 & 합계 \\
\hline \multirow{11}{*}{2008} & 냉장고 & 0 & 27,046 & 574 & 1,951 & 11,671 & 478 & 2,855 & 44,575 \\
\hline & 세탁기 & 0 & 9,566 & 351 & 1,295 & 7,011 & 73 & 2,221 & 20,518 \\
\hline & 에어컨 & 0 & 1,162 & 46 & 174 & 520 & 34 & 383 & 2,320 \\
\hline & TV & 0 & 3,253 & 9 & 538 & 3,339 & 10,698 & 1,335 & 19,171 \\
\hline & 컴퓨터 & 6,953 & 1,304 & 18 & 291 & 314 & 330 & 261 & 9,472 \\
\hline & 오디오 & 0 & 398 & 12 & 63 & 349 & 0 & 141 & 963 \\
\hline & $\begin{array}{c}\text { 이동전화 } \\
\text { 단말기 }\end{array}$ & 0 & 5 & 1 & 210 & 266 & 0 & 196 & 677 \\
\hline & 프린터 & 0 & 488 & 10 & 55 & 401 & 17 & 50 & 1,021 \\
\hline & 복사기 & 0 & 310 & 1 & 5 & 95 & 9 & 32 & 452 \\
\hline & 팩시밀리 & 0 & 47 & 0 & 4 & 39 & 0 & 6 & 96 \\
\hline & 합계 & 6,953 & 43,579 & 1,022 & 4,586 & 24,006 & 11,639 & 7,480 & 99,265 \\
\hline \multirow{11}{*}{2009} & 냉장고 & 0 & 27,775 & 682 & 1,928 & 12,756 & 501 & 3,415 & 47,056 \\
\hline & 세탁기 & 0 & 11,260 & 524 & 1,952 & 7,339 & 146 & 2,289 & 23,510 \\
\hline & 에어컨 & 0 & 1,372 & 86 & 264 & 291 & 6 & 246 & 2,265 \\
\hline & TV & 0 & 3,131 & 33 & 431 & 3,232 & 9,490 & 1,213 & 17,531 \\
\hline & 컴퓨터 & 6,243 & 912 & 11 & 225 & 216 & 0 & 85 & 7,692 \\
\hline & 오디오 & 0 & 272 & 12 & 45 & 200 & 0 & 52 & 581 \\
\hline & $\begin{array}{c}\text { 이동전화 } \\
\text { 단말기 }\end{array}$ & 0 & 11 & 7 & 240 & 267 & 0 & 69 & 593 \\
\hline & 프린터 & 1 & 511 & 3 & 60 & 457 & 1 & 21 & 1,054 \\
\hline & 복사기 & 0 & 211 & 10 & 6 & 91 & 6 & 19 & 344 \\
\hline & 팩시밀리 & 0 & 54 & 0 & 3 & 43 & 0 & 4 & 104 \\
\hline & 합계 & 6,244 & 45,511 & 1,368 & 5,155 & 24,892 & 10,151 & 7,412 & 100,733 \\
\hline
\end{tabular}

Table 10. Chemical composition of the waste catalyst generated from the desulfurization of petroleum

(단위 : wt \%)

\begin{tabular}{|c|c|c|c|c|c|c|c|c|c|}
\hline 종류 & $\mathrm{Mo}$ & $\mathrm{V}$ & $\mathrm{Ni}$ & $\mathrm{Co}$ & $\mathrm{Fe}$ & $\mathrm{P}$ & $\mathrm{S}$ & $\mathrm{Al}$ & 수분+유분 \\
\hline 직탈 촉매 & $3 \sim 6$ & $0.5 \sim 12$ & $2 \sim 3$ & $0.5 \sim 1$ & $0.5 \sim 1$ & $<0.1$ & $8 \sim 12$ & bal. & $5 \sim 20$ \\
\hline 간탈 촉매 & $6 \sim 9$ & $<0.5$ & $0.5 \sim 1$ & $1.5 \sim 3$ & $1 \sim 2$ & $0.5 \sim 3$ & $3 \sim 8$ & bal & $3 \sim 15$ \\
\hline
\end{tabular}

Table 11. Generation of the waste desulfurization catalyst from the petroleum processing

( 단위 : 톤)

\begin{tabular}{|c|c|c|c|c|c|c|c|c|c|c|c|}
\hline 연도 공정 & 1993 & 1995 & 1996 & 1997 & 1998 & 2001 & 2002 & 2004 & 2007 & 2008 & $2009^{*}$ \\
\hline VR-HDS & 1,300 & 1,300 & 1,300 & 3,500 & 5,500 & 5,500 & 5,500 & 9,000 & 9,000 & 11,000 & 11,000 \\
\hline AR-HDS & 0 & 0 & 0 & 3,000 & 3,000 & 3,000 & 3,000 & 3,000 & 3,000 & 3,000 & 7,000 \\
\hline R-FCC & 0 & 2,000 & 10,000 & 16,000 & 20,000 & 20,000 & 20,000 & 20,000 & 20,000 & 20,000 & 28,000 \\
\hline
\end{tabular}

*현재 증설이 완료되어 가동 중인 공정에서 촉매 사용기간을 감안하여 2009년도에 발생한 폐촉매를 계산하였음.

J. of Korean Inst. Resources Recycling Vol. 20, No. 6, 2011 


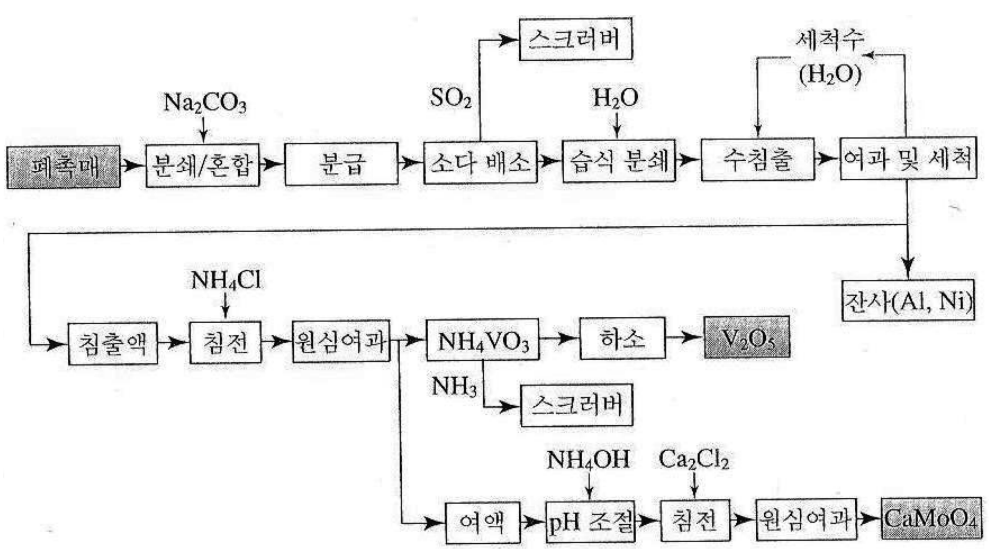

Fig. 4. Processing flow sheet of the waste desulfurization catalyst.

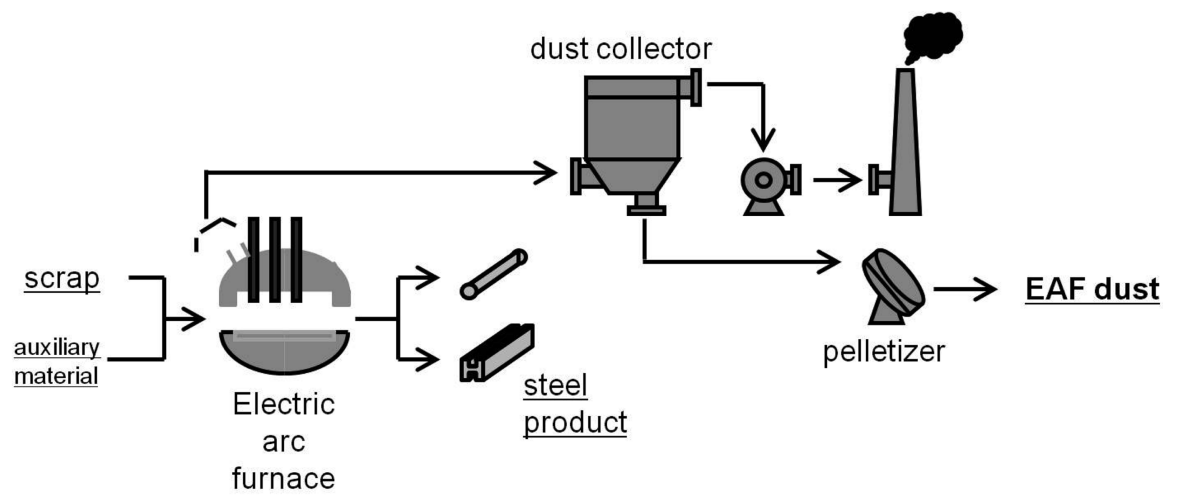

Fig. 5. Generation of the EAF dust from the electric arc furnace.

Table 12. Typical composition of EAFD

\begin{tabular}{|c|c|}
\hline Constituent & Content (wt\%) \\
\hline $\mathrm{ZnO}$ & $13-30$ (typically $18-26)$ \\
\hline $\mathrm{Fe}$ & $28-38$ \\
\hline $\mathrm{Pb}$ & $1-6($ usually 1$)$ \\
\hline $\mathrm{CaO}$ & $4-5$ \\
\hline $\mathrm{Mn}$ & 2 (typically 4$)$ \\
\hline $\mathrm{Mg}$ & $1.3 \mathrm{max}$. \\
\hline $\mathrm{Cl}$ & $300-500 \mathrm{ppm}$ \\
\hline $\mathrm{F}$ & $<0.025$ \\
\hline $\mathrm{Cd}$ & $1-7$ \\
\hline $\mathrm{Cr}$ & \\
\hline
\end{tabular}

으로 늦은 감은 있으나 다음 두 회사가 현재 $\mathrm{EAF}$ dust 리싸이클링공장을 건설하였고, 또 건설 중에 있다.
(1) 한국아연(주)

한국제강(주)가 투자하여 2009년 경남 함안군 칠원면 에 10 만톤 처리규모의 공장(Fig. 6 참조)을 건설하였으 나, 행정상의 어려움으로 현재 안타깝게도 가동대기 중 이다. 이 공장의 process flow sheet는 Fig. 7과 같으 며 일본의 Sotetsu Metal(曹鐵メタル)의 process와 흡사 하다.

함안(咸安) plant의 처리공정은 두 공정으로부터 성립 되었으며, 제1공정에서는 No. 1 rotary kiln에 의해서 $\mathrm{EAF}$ dust의 환원 휘발 배소를 행하여 제강 더스트 중 에 함유되어 있는 아연을 환원한다. 고온이기 때문에 가 스상으로 된 아연은 로내에서 산화아연 미립자가 되어 집진장치에 의해서 포집된다. 산화아연 더스트 중에는 $\mathrm{Pb}, \mathrm{Cd}, \mathrm{Na}, \mathrm{K}, \mathrm{Cl}, \mathrm{F}$ 등이 혼입되어 있기 때문에 조 산화아연이라고 한다. 제 2 의 공정에서는 산화분위기로 유지된 고온의 No. 2 Rotary kiln에 의해서 조산화아 연을 처리하고, 혼입된 제 성분을 휘발 분리해서 정제 


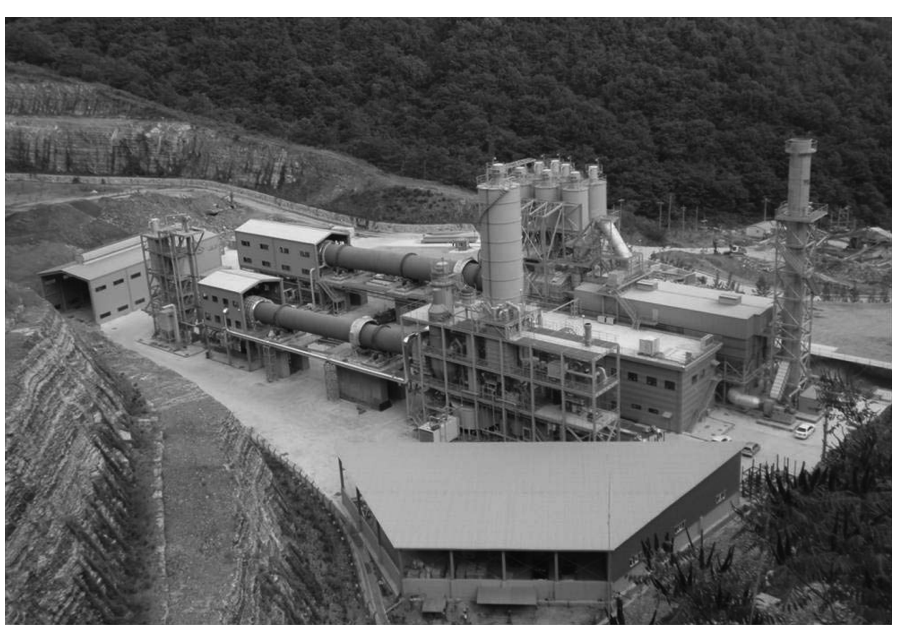

Fig. 6. The EAF dust recycling plant located at Haman, Gyeongsangnam-do.

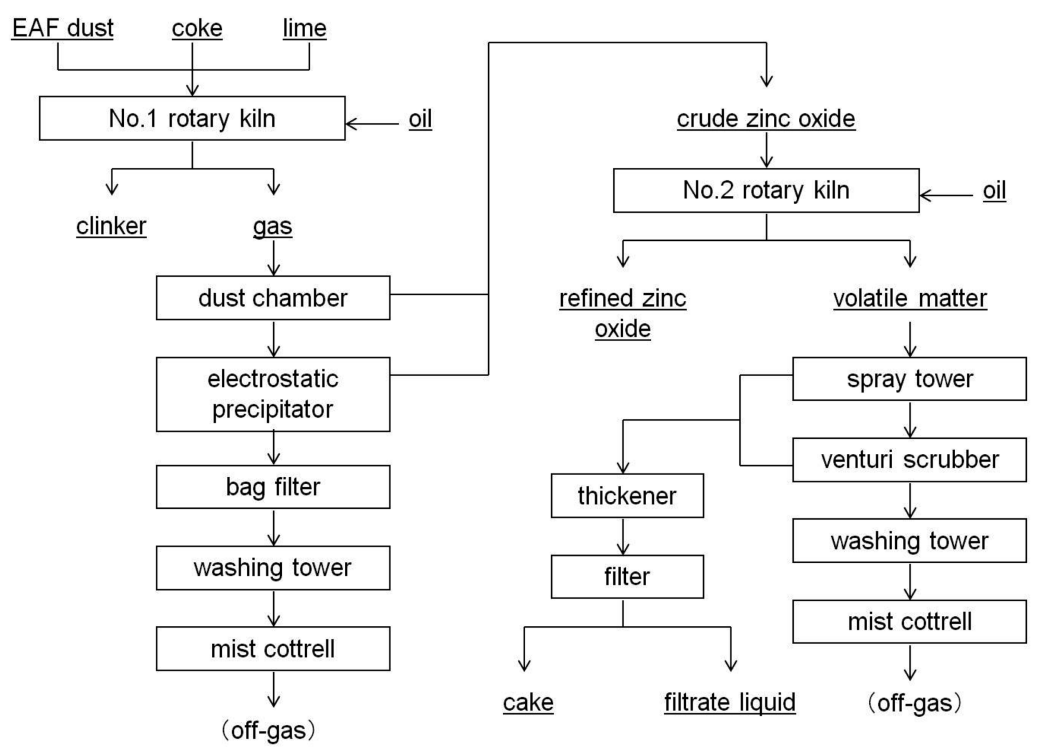

Fig. 7. Process flow sheet of the Haman plant.

산화아연으로 만든다. 이 정제 산화아연으로부터 阿座 上 竹四 교수가 개발한 철환원휘발법(Fig. 8 참조)에 의 해서 금속아연을 직접 회수하려고 시도하고 있다.

\section{(2) $\operatorname{ZincOX}(\text { 주 })^{18)}$}

고려아연(주)가 투자하여 $\mathrm{ZincOX(주)와} \mathrm{공동으로}$ 2011년 4월 경주산업단지 내에 10만톤 처리규모의 rotary hearth furnace process에 의한 공장건설이 시작 되었다. 2012년 초에는 가동이 기대된다.

\section{6. 맺는말}

본고의 주목적은 한국의 금속소비량 제시에 있다. 소 비량 통계표 작성에 있어 그 신뢰성에 약간의 불안감도 있다. 금속축적량의 추정은 더욱 불안감을 가중시킨다. 그러나 대담하게도 금속소비량 통계표를 제시하였다. 본 고의 다른 목적은 한국의 도시광산 재자원화산업을 개 관하는데 있다. 


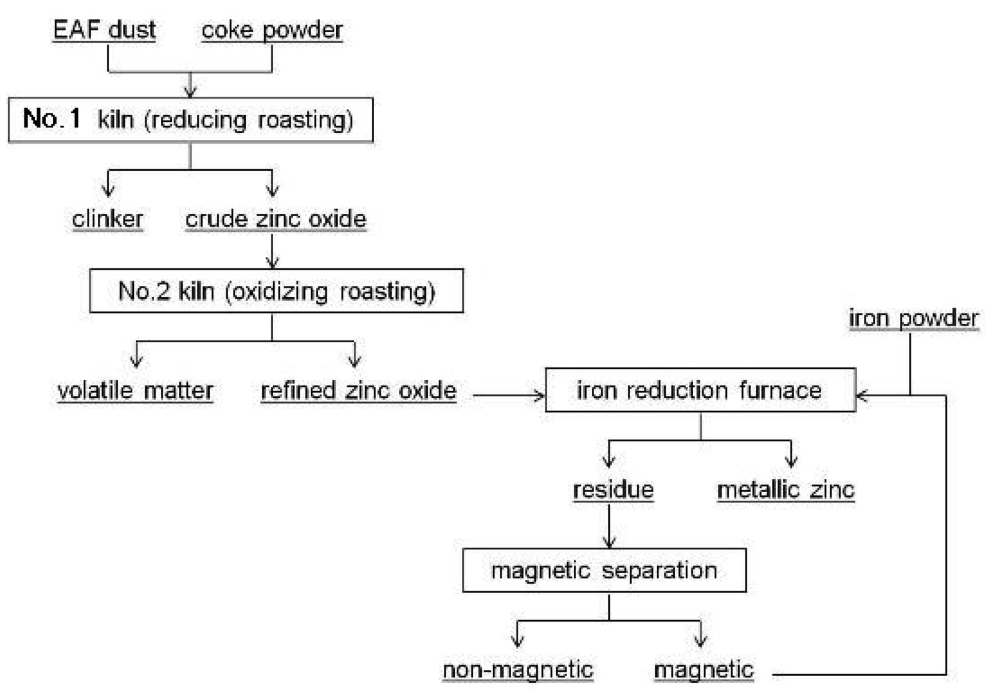

Fig. 8. Flow sheet for EAF dust processing proposed by Prof. Azakami at the Haman plant.

도시광산 재자원화산업의 탐색에 있어서 bottom up 방식으로 또는 top down 방식으로 조사한 것이다. 본 고가 국내 금속소비량 통계를 지속적으로 작성하는데 바탕이 되기를 기대하고, 도시광산 재자원화산업을 파 악하는데 도움이 되기를 바란다.

\section{감사의 글}

본 연구는 국가청정생산지원센터의 에너지정보화 및 정책지원사업의 일환으로 수행되었으며, 본 연구를 지 원해주신 국가청정생산지원센터에 감사드립니다.

\section{참고문헌}

1. T.E.Graedel, 2011: The prospects for urban mining, The Bridge, Spring 2011, pp. 43-50.

2. 한국비철금속협회 내부자료, 2011.

3. 한국철강협회, 2011: 철강통계연보 2011

4. 관세청 HS code 내부자료, 2011.

5. 한국비철금속협회, 2008: 산업용 원자재 중장기 수급안정 화 방안연구(희유금속을 중심으로) 보고서, 한국비철금속 협회.

6. LS-Nikko동제련(주), 고려아연(주), 2011: LS-Nikko copper 및 Korea Zinc 홍보물

7. 박형규, 강민철, 2011: 국내 마그네슘 스크랩 리싸이클링 현황, 2011년도 춘계임시총회 및 제36회 학술발표대회 자
료집, pp. 49-53, 한국자원리싸이클링학회

8. 우상모, 2011: 탄탈륨사업 추진전략, 비철금속 제조 및 응 용 심포지엄 자료집, (사)대한금속·재료학회 비철금속 분 과위원회

9. 오재현, 김준수, 문석민, 민지원, 2010: 日本의 都市鑛山( 사용후제품) 資源과 金屬再資源化座業, 資源리싸이클링, 19(6), pp. 11-26, 한국자원리싸이클링학회.

10. ibid 9)

11. 오재현, 김준수 외 2명, 2011: 曫革期의 韓國 自動車 리 싸이클링시스템과 發展課題, 資源리사이클링, 20(2), pp. 16-29, 한국자원리싸이클링학회.

12. LG환경연구원, 2006: 자동차 재활용 전략수립 보고서, p.81, LG환경연구원.

13. 日本自動車工業協會, 2002: 日本の自動車工業, p.51, 日本 自動車工業協會

14. 오재현, 김준수 외 2명, 2011: 韓國의 E-waste 리싸이클 링시스템과 再, 資源化 產業, 資源리사이클링, 20(5), pp. 16-33, 한국자원리싸이클링학회.

15. 장용철, 강희석 외 6명, 2008: 폐휴대폰의 발생량 산정, 수거 및 유통체계, 한국폐기물학회지, 25(1), pp. 82-89.

16. 이재천, 이진영, 2009: 페촉매 재활용(일반 금속 폐촉매 재활용), 리싸이클링 백서(2009), pp. 287-292, 한국자원 리싸이클링학회, 자원재활용기술개발사업단.

17. 윤재홍, 2009: 한국아연(주)의 전기로 제강분진 자원화설 비 현황 및 운전, 제철/제강분진 자원화 국제심포지엄 자 료집, pp. 109-122, 한국자원리싸이클링학회.

18. 고려아연(주) 내부자료 


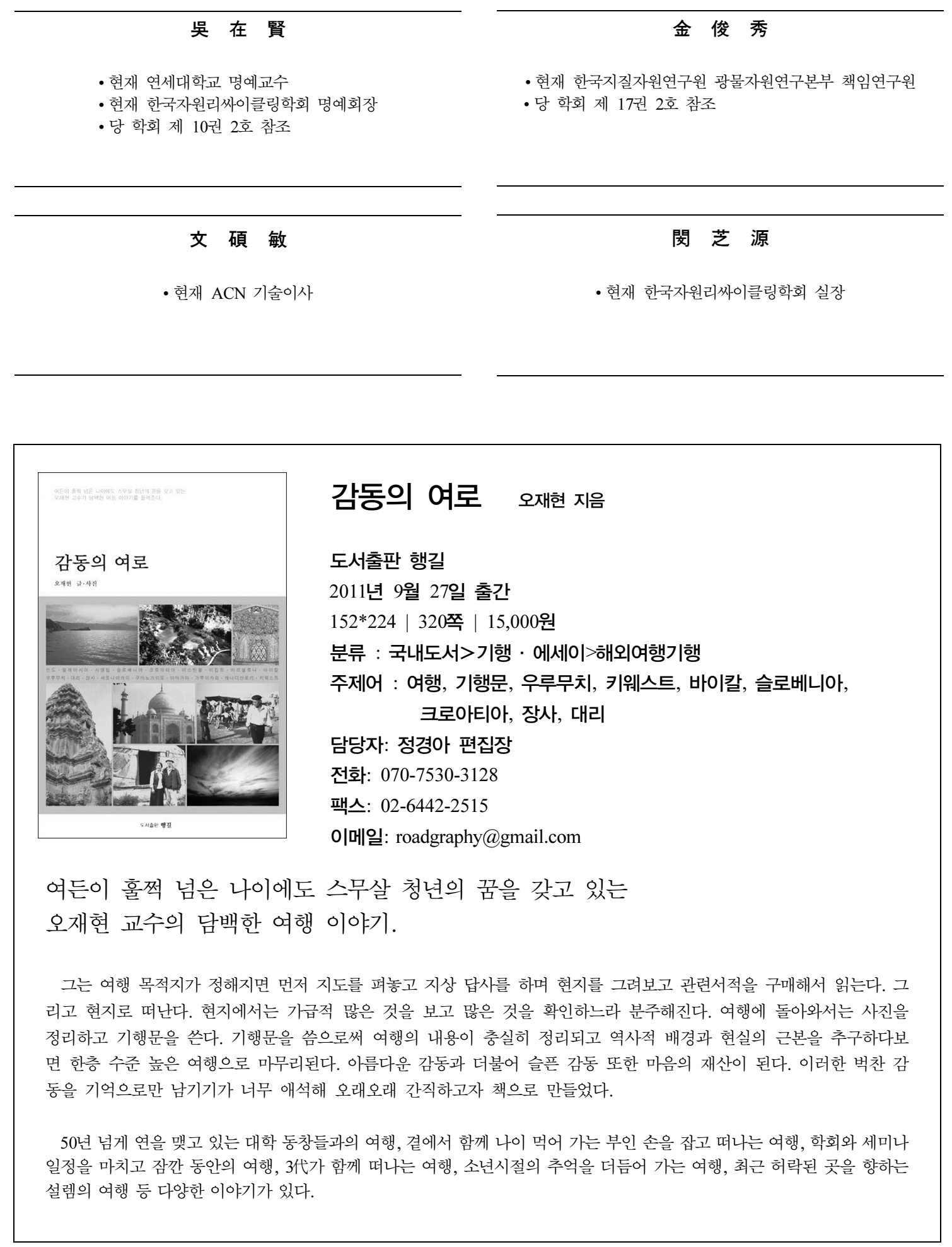

